\title{
Translating Movie Titles: Strategies Applied on Persian to English Cases
}

\author{
Sobhan Shokri \\ Faculty of Foreign Languages, University of Isfahan, Iran \\ Email:sbn.shokri@gmail.com
}

\section{Doi:10.5901/mjss.2014.v5n20p2568}

\begin{abstract}
Movies are significant art forms that can potentially reflect life, culture, world, or thought of a society and present it to another society. Movie titles are the indivisible part of the movies. Translating movie titles is an arduous activity owing to its leading role in movies. Foreign movies are rapidly translated from English to Persian, while translation of Persian movies to English still has not received much attention. Therefore, the present study attempts to investigate the translation of 64 Persian movie titles with the intention of analyzing translation strategies used. The model proposed by Vinay and Darbelnet was used as the theoretical framework of this study to check up on each strategy used for translation of these 64 Persian to English movie titles. The results show that the most frequent translation strategy is literal translation in the translation of movie title from Persian to English, which is in line with the results of English to Persian, or English to Chinese translation of movie titles which were done in other studies.
\end{abstract}

Keywords: Movie titles; Vinay and Darbelnet; Translation strategies; Literal translation;

\section{Introduction}

Formerly, there are a lot of movies that are introduced to Iran. Movie is one of the most influential media in the world that potentially can introduce beliefs and culture of a group of people to another group. Title is the appellation given to the movies, which may behold the theme or plot of the movie; therefore, they are the indivisible part of the movies. Movie titles are the catchy phrases that are the first thing to spread about the upcoming movies, and an accepted translation may play a role in the successful release of a movie. This adds to the importance of the fact that translation of movie titles is a serious job which needs much effort.

In the translation of movie titles, much attention should be paid to the features of the title to see whether it is connected to the plot or characters of the movie. To do so, different translation strategies and procedures are introduce. Venuti (2000) states that adaptation is one the most frequently used strategy in the translation of books and movie titles.

\section{Literature Review}

Newmark, in his A textbook of translation, distinguishes between 'descriptive titles', which describe the topic of the text, and 'allusive titles', which have some kind of referential or figurative relationship to the topic (1988, p. 57). He, then, suggests that for literary texts, a descriptive title should be 'literally' kept, and an allusive title should be preserved imaginatively. For non-literary texts, there is always a request for replacing allusive by descriptive titles, particularly if the allusive title is idiomatic or culturally bound.

There are many studies previously done in this area which have investigated the translation of movie titles. Ying (2007) investigated the translation of movie titles from English to Chinese by applying Newmark's translation procedures. Four main translation procedures identified were literal translation, transliteration, free translation and semantic translation. It was suggested that a translator could provide suitable translations to "get the audience a better understanding of the film itself" by integrating different translation strategies and procedures with a theory.

In another study, Yin (2009) studied the translation of movie titles from English to Chinese. In this study, techniques used in translating movie titles were classified into two groups: 1. transliteration, literal, and explication, which show respect for the original title, and 2. Adaptation and providing a new title, which get rid of the original title. As Yin proposed, a good movie title "should obey faithfulness, cultural awareness, combination of commercial and aesthetic effects."

Finally, Lotfollahi and Moinzadeh (2012) examined the translation procedures used for translating movie titles from English to Persian. They centered their study on 60 Hollywood movies of 2010 from English to Persian. The results of 
their study show that the most frequently used strategies were literal translation and transliteration.

Iran, for long, has been a decent market for foreign movies. Many foreign movies are either dubbed or subtitled from English to Persian each year. However, the other way round, is just becoming a trend in three ways:

1. Movies which are dubbed into other languages, e.g. the Oscar-winning movie, a separation.

2. Movies which are subtitled into English, in which the title is translated as well.

3. No dubbing or subtitling is done, just the producers of Persian movies, or sellers of Persian movies decide to include the English translation of their movie in order to advertise in worldwide and for presenting them to nonPersian speakers.

\subsection{Translation Procedures}

Vinay and Darbelnet's model of translation is set as the theoretical framework of this study. The following seven translation 'procedures' were identified by them, which are classified into two groups (Munday, Introducing Translation Studies, 2008, pp. 56-58):

I. Direct translation:

1. Borrowing: It happens when the source language word is transferred directly to the target language.

2. Calque: It is "a special kind of borrowing" where the source language expression or structure is transferred literally.

3. Literal translation: It is "word-for-word" translation and is common between languages of the same family and culture.

II. Oblique translation:

4. Transposition: It happens when one part of speech changes for another without changing the sense.

5. Modulation: It changes the point of view and semantics of the source language.

6. Equivalence: This is used when "languages describe the same situation by different stylistic or structural means" especially in translating proverbs and idioms.

7. Adaptation: Where a situation in the source culture does not exist in the target culture, adaptation happens by changing the cultural reference.

\section{Research Methodology}

A list of 64 Persian movies, which has been translated from Persian to English, was made from the websites that introduce or sell these movies in foreign markets. Each title was compared with its English counterpart so as to define the type of translation strategy used. The theoretical framework of this study is Vinay and Darbelnet's model, since this is a comprehensive model in the translation of movie titles owning to its having the adaptation strategy; Venuti (2012) states that adaptation is one the most frequently used strategy in the translation of books and movie titles. All 64 items are studied to investigate what type of translation strategy is used, and then the items are categorized in groups. At last, frequency and percentage of each strategy is calculated separately to see which strategy is more frequently used.

\section{Findings and Discussion}

Vinay and Darbelnet's model can fall into two categories: 1. Showing respect for the original title (borrowing, calque, literal translation), and 2. Neglecting or alleviating the original title (transposition, modulation, equivalence, adaptation). 
Table 1. Borrowing

In this strategy, both borrowed words from SL and transliteration form of SL words are considered. Mostly, movies which are proper names of people or places are treated in this category, e.g. نركسwich is translated as Narges.

\begin{tabular}{|c|c|}
\hline 1. لبلا /Leilā/ & Leila \\
\hline 2. صنم/Sanam/ & Sanam \\
\hline 3. 3اجى و اشينكتون/Hāji Washington/ & Haji Washington \\
\hline 4. سارا ا ISārā// & Sarah \\
\hline 5. كانى مانعا /Kānimāngā/ & Kanimanga \\
\hline 6. زينت /Zinat/ & Zinat \\
\hline 7. نركس /Narges/ & Narges \\
\hline 8. دنيا /Donyā/ & Donya \\
\hline 9. بـرى /Pari/ & Pari \\
\hline 10. هامون /Hāmūn/ & Hamoon \\
\hline 11. سياوش/Siāvash/ & Siavash \\
\hline
\end{tabular}

Table 2. Literal translation

Most cases are related to this category. Literals translation or word-for-word translation is the most frequent strategy in

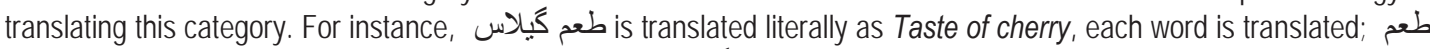
is translated as Taste and Cherry is the equivalence of كيلاس. Other examples can be زكان wich is translated as Women's Prison, and which is translated as Cow.

\begin{tabular}{|c|c|c|}
\hline 1. & lin yek film nist/ & This is not a film \\
\hline 2. & L كثتز ارهاى سبيد & The white meadows \\
\hline 3. & L IDāyere-ye minā/ & Mina circle \\
\hline 4. & / تهر ان من حر اج /Tehrān-e man harāj/ & My Tehran for sale \\
\hline 5. & شكارجى/Shekārchi/ & The Hunter \\
\hline 6. & /Zanān bedūne mardān/ زنان بذون مردان/ & Women without men \\
\hline 7. & 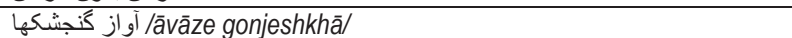 & The song of sparrows \\
\hline 8. & / بند كيلو خرما براى مر اسم تدفين /chand kilū khormā barāye marāseme tadfin/ & A few kilos of date for a funeral \\
\hline 9. & /nime māh/ & Half moon \\
\hline & lDerakhte goläbi/ & The pear tree \\
\hline & ldom-e mār/ & Snake's tail \\
\hline & / مردان مشغول كار/mardān mashghul-e kār/ & Men at work \\
\hline & lâtash bas/ & Ceasefire \\
\hline & تله /tale/ & Trap \\
\hline & إير درخت هلو/zire derakhte holu/ & Under the peach tree \\
\hline & 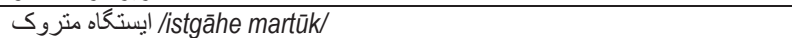 & Deserted station \\
\hline & كأ /gāv/ & Cow \\
\hline 18. & /bachehāye bad/ & Bad kids \\
\hline & L دستفروش/dastforūsh/ & peddler \\
\hline 20. & برده آخر /parde-ye ākhar/ & The last act \\
\hline 21. & إنه سياه است /khāne siah ast/ & House is black \\
\hline 22. & l/sib/ سيب & Apple \\
\hline & المعم كيلاس/tam-e gilās/ & Taste of Cherry \\
\hline 24. & 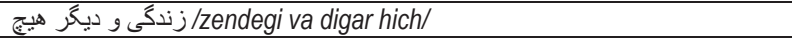 & Life and nothing more \\
\hline 25 & لها نهام بدر /be nāme pedar/ & In the name of Father \\
\hline 26. & / خانه دوست كجاست؟ /khāne dūst kojāst? / & Where's Friend's Home? \\
\hline 27. & إنist angosht/ & 20 Fingers \\
\hline & lئ يك شب /yek shab/ & One Night \\
\hline & بادكنك سفيد /bādkonak-e sefid/ & White Balloon \\
\hline & l/mostajerān/ & Tenants \\
\hline & ا دوحِ خه سوار/docharkhe savār/ & Cyclist \\
\hline 32. & lavande/ & Runner \\
\hline
\end{tabular}




\begin{tabular}{|c|c|}
\hline 33. خو اب سفبد/khāb-e sefid/ & White Dream \\
\hline 34. خاكسترى /khākestari/ & Gray \\
\hline 35. ز زندان زنان/zendāne zanān/ & Women's Prison \\
\hline 36. شازده احتجاب/shāzde ehtejāb/ & Prince Ehtejab \\
\hline 37. ارتفاع يست /ertefā-e past/ & Low Heights \\
\hline 38. شام آخر/shām-e akhar/ & Last Supper \\
\hline 39. مهمانان هنل آستوريا /mehmānan-e hotel āsturiā/ & Guests of Hotel Astoria \\
\hline
\end{tabular}

Table 3. Modulation

Modulation refers to any change in the point of view and semantics of the source language; therefore, دستهاى آلوده is translated as Corrupted hands, in which there is a slight change in the meaning of آلوده. Pastry Girl, too, refers to a girl who bakes pie and sweets, while the Persian word refers to a girl who sells them.

\begin{tabular}{|c|c|}
\hline 1. دستهاى آلوده /dasthāye ālude/ & Corrupted hands \\
\hline 2. دختر شيرينى فروش/dokhtare shirini forūsh/ & Pastry Girl \\
\hline
\end{tabular}

Table 4. Adaptation

Adaptation deals with changing the cultural reference. جهارشنبه سورى does not exist in English, consequently, the translator has used fireworks instead. Twilight also refers to a new genre of movies which cannot be equivalent of

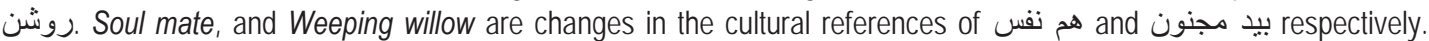
Tunes of Nostalgia is name of a music album in TL which shows a change in the source reference.

\begin{tabular}{|c|c|}
\hline 1. جهارشنبه سورى /chāhār shanbe sūril & Fireworks Wednesday \\
\hline 2. سايه روشن/sāye roshan/ & Twilight \\
\hline 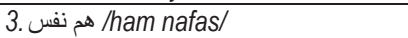 & Soul mate \\
\hline 4. بيد مجنون/bid-e majnūn/ & Weeping Willow \\
\hline 5. آهنخ غربت /âhange ghorbat/ & Tunes of Nostalgia \\
\hline
\end{tabular}

Table 5. Equivalence

Equivalence refers to verbalization of the same situation by different stylistic or structural means in another language. This denotes two cases: firstly, translating proverbs and idioms which needs a total change in form and deviates totally from literal translation, and secondly, translation of ST item with some stylistic or structural changes which naturalizes the target equivalent. جدايى نادر از سيمين is translated as A separation, and توكيو بدون توقف is translated as Tokyo, Nonstop.

\begin{tabular}{|c|c|}
\hline 1. جدايى نادر از سيمين/jodāie nāder az simin/ & A separation \\
\hline 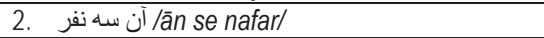 & Those Three \\
\hline 3. كيى برابر اصل/kopi barābare asl/ & Certified copy \\
\hline 4. فوتبال زير حجاب /fūtbāl zire hejāb/ & Football under cover \\
\hline 5. دم صبح/dam-e sobh/ & Day break \\
\hline 6. از كنار هم مى كَذريم /az kenāre ham migozrim/ & Going by \\
\hline 7. توكيو بدون توقق/Tokyo, bedūne tavaghof/ & Tokyo, Non-stop \\
\hline
\end{tabular}

\section{Results}

It is obvious that 'literal translation' is the most frequent strategy with 39 occurrences. Frequency of each strategy is presented in Figure 1: 


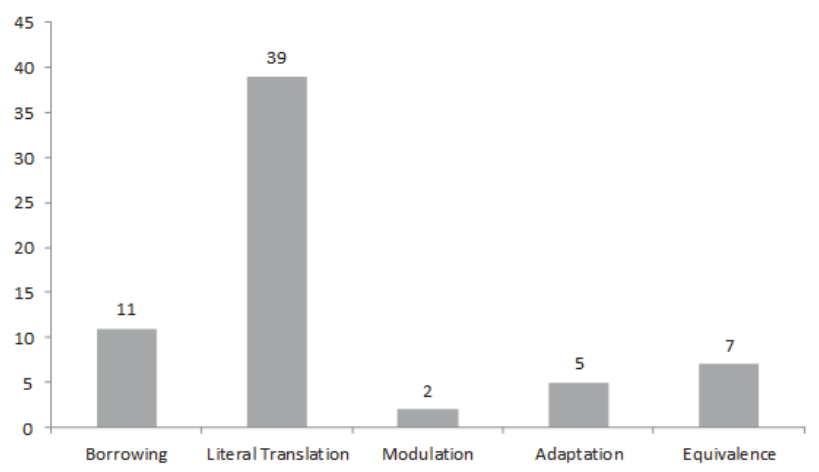

Figure 1. Frequency of translation strategies

Also the percentage of translation strategies used is presented in figure 2:

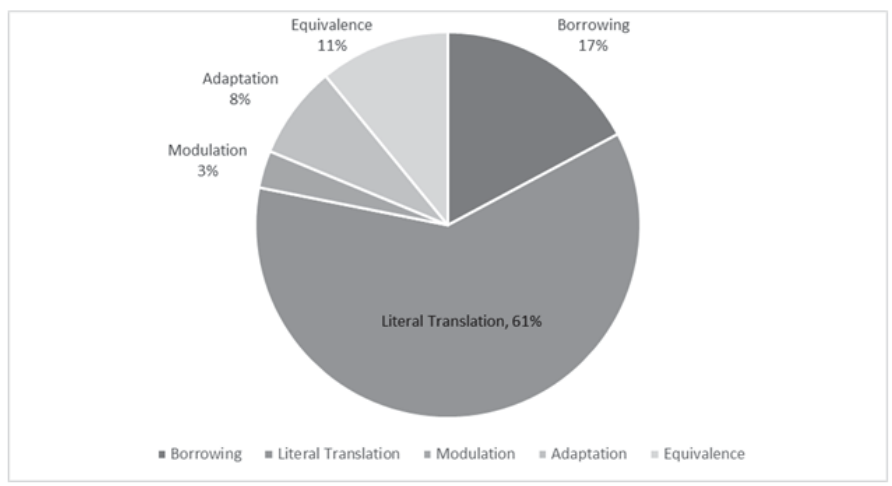

Figure 2. Percentage of Translation Strategies

The results show that preserving the source title is the best strategy, since the purpose of 'literal translation' with $61 \%$ and 'borrowing' with $17 \%$ is to stick to the source title. Strategies of oblique translation, equivalence with $11 \%$, adaptation with $8 \%$, and modulation with $3 \%$ also refers to those cases in which there is a deviation from the source title.

\section{Concluding Remarks}

Movie titles attract non-professional movie-goers, and to some extent the professional ones, in the first place. It may affect the box-office success of a movie. Therefore, a good translation of the source title plays the same role for the target audience.

The present study investigated the translation of 64 movies titles from Persian to English. Gathering movies which are subtitled, dubbed, or even had their titles translated was a demanding job itself, since there are few movies which are presented from Iran's cinema to the foreign markets. Vinay and Darbelnet's model was set as the theoretical framework of this study. The results show that literal translation is the most frequent strategy in translating movie titles from Persian to English.

There are similar studies on translation of movie titles from English to other languages. For the case of English to Persian, Lotfollahi and Moinzadeh (2012) found that literal translation and transliteration are the most frequent translation strategy. Ying (2007) found that literal translation is the most frequent strategy for English to Chinese movie titles translation. Yet, there was no previous study on Persian to English translation of movie titles. However, the result of this study is in line with the results of English to Persian or Chinese studies done previously. 


\section{References}

Baker, M., \& Saldanha, G. (2009). The Routledge Encyclopedia of Translation Studies (2nd ed.). London: Routledge.

Iranian Movies. (n.d.). (Iranian Movies Incorporation) Retrieved July 9, 2013, from http://www.iranianmovies.com/

Lotfollahi, B., \& Moinzadeh, A. (2012, September). Translation of Movie Titles from English into Persian: Strategies and Effects. Mediterranean Journal of Social Sciences, 3(3), 511-516. doi:10.5901/mjss.2012.v3n3p511

Munday, J. (2008). Introducing Translation Studies (2nd ed.). New York: Routlege.

Munday, J. (2009). The Routledge Companion to Translation Studies. New York: Routledge.

Newmark, P. (1988). A Textbook of Translation. London: Prentice Hall.

Venuti, L. (2000). The translation studies reader. London and New York: Routledge.

Yin, L. (2009). On the translation of English movie titles. Asian social science, 5(3), 171-173. Retrieved from http://ccsenet.org/ journal/index.php/ass/article/view/268/242

Ying, P. (2007). Translation of film titles with the application of Peter Newmarks's translation theory. Sino-Us English teaching,, 4(4), 77 81. Retrieved from http://www.docstoc.com/docs/27370313/Translation-of-Film-Titles-with-the-Application-of-Peter 